\title{
FAKTOR - FAKTOR YANG MEMPENGARUHI TINGKAT HUNIAN KAMAR PADA HOTEL DI KOTA JEMBER
}

\author{
Hadi Jatmiko ${ }^{1}$, Syah Riza Octavy Sandy ${ }^{2}$ \\ Program Perhotelan, Fakultas Ilmu Sosial dan Ilmu Politik \\ Universitas Muhammadiyah Jember, Indonesia \\ Email : hadijatmiko@unmuhjember.ac.id
}

\begin{abstract}
Abstrak
Sumber daya manusia dalam bidang perhotelan sudah tidak sulit lagi untuk di peroleh tetapi dalam memenuhi sumber daya manusia yang professional, handal, serta mempunyai dedikasi dan disiplin masih terbatas. Hal ini dapat dilihat dari kecenderungan para karyawan sebuah hotel khususnya hotel kecil masih mengabaikan penampilan dalam menunjang pelayan, hal dapat terlihat dari tingkat hunian kamar yang labil. Fenomena seperti ini tidak dapat dilihat dari satu sisi saja, yaitu dari staf (karyawan) semata, tetapi dari beberapa faktor yang mempengaruhi pola para karyawan dalam memberikan pelayanan. Penelitian ini bertujuan Untuk mengetahui faktor-faktor yang mempengaruhi tingkat hunian kamar hotel di kota Jember Analisa data yang digunakan adalah deskriptif kualitatif dengan jumlah sampel 75 responden karyawan hotel, dan 150 responden pengunjung hotel. Hasil penelitian menunjukan bahwa (1) faktor internal, kemampuan staff, aksesbilitas, dan fasilitas kamar berpengaruh signifikan secara bersama-sama terhadap tingkat hunian kamar hotel di Jember, (2) bahwa faktor internal, kemampuan staff, aksesbilitas, dan fasilitas kamar berpengaruh signifikan secara parsial terhadap tingkat hunian kamar hotel di Jember, adapun pengaruh paling dominan terletak pada kemampuan staf.
\end{abstract}

Kata Kunci : Karyawan Hotel, Pelayanan, Tingkat Hunian Kamar

\begin{abstract}
Human resources in the hospitality sector are not difficult to obtain but in fulfilling professional, reliable, and dedicated dedication and discipline human resources are still limited. This can be seen from the tendency of the employees of a hotel, especially small hotels to still ignore the appearance in supporting the servants, it can be seen from the unstable room occupancy rate. This phenomenon can not be seen from one side only, namely from the staff (employees) only, but from several factors that affect the pattern of employees in providing services. This study aims to determine the factors that influence the hotel room occupancy rate in Jember. The data analysis used is descriptive qualitative with a sample of 75 respondents of hotel employees, and 150 respondents of hotel visitors. The results showed that (1) internal factors, the ability of staff, accessibility, and room facilities had a significant effect together on the hotel room occupancy rate in Jember, (2) that internal factors, staff ability, accessibility, and room facilities had a significant effect partial to the hotel room occupancy rate in Jember, while the most dominant influence lies in the ability of staff.
\end{abstract}

Keywords: Hotel Employees, Service, Room Occupancy. 


\section{INTRODUCTION}

Karyawan merupakan representasi dari tingkat pelayanan yang diberikan kepada tamu yang selama menginap di hotel, oleh sebab itu di butuhkan seorang yang mempunyai kemampuan yang tinggi, baik dalam keakuratan pekerjaan sampai pada penampilannya. Pada dasarnya pelayanan yang diberika kepada tamu akan memberikan rasa nyaman dan puas kepada tamu, dengan harapan suatu saat tamu dapat menginap kembali.

Pelayanan menurut fee (dalam Mustika, 2002) adalah pemenuhan harapan konsumen dalam rangkaian penjualan dan aktifitas paska penjualan melelui pembelian serangkaian fungsi yang sesuai atau lebih baik,yang dapat memberikan tambahan keuntungan bagi penyedia jasa kemudian. Sulastyono (2001) menambahkan bahwa pelayanan adalah "sesuatu yang dapat dibeli dan dijual akan tetapi tidak dapat dilihat fisiknya"

Perkembangan hotel di Jember tumbuh dengan signifikan, hal ini dapat terlihat dari berdirinya beberpa hotel berjaringan di Jember, akan tetapi persaingan yang mengakibatkan tingkat hunian kamar masing - masing hotel bervariasi. dikutip dari pernyataan Ketua PHRI cabang Jember, bahwa pertumbuhan usaha hotel di Jember semakiin meningkat. Kompetisi untuk mendapatkan tamu atau pelanggan dengan fasilitas hotel dan pelayanan yang prima telah meningkat pula.

Menurut Endar Sugiarto (2002:55), tingkat hunian adalah suatu keadaan sampai sejauh mana jumlah kamar yang terjual jika dibandingkan dengan seluruh jumlah kamar yang mampu untuk dijual. Tingkat hunian kamar yang tinggi sebuah hotel maka akan dapat memberikan keuntungan dan penghasilan yang tinggi bagi hotel tersebut. Hal ini dikarenakan kamar sebagai sebagai produk utama yang memberikan profit margin yang paling tinggi dibandingkan dengan produk - produk hotel lainnya seperti laundry, bar, restaurant, room service, dan lain sebagaimnya.

Menurut Sugiarto (2002:10) tingkat hunian adalah tolak ukur keberhasilan sebuah hotel. Sementara itu, Sulastiyono (2008:269) menuliskan bahwa hotel yang berhasil akan terlihat dari tingkat hunian kamarnya. Maka dapat disimpulkan bahwa dengan tingginya tingkat hunian kamar sebuah hotel, secara tidak langsung akan mempengaruhi penghasilan dan keuntungan hotel tersebut. Menurut prakteknya, hal ini di karenakan pendapatan yang diperoleh dari hasil penjualan kamar hampir setengah dari pendapatan hotel rata - rata

Sedangkan menurut Suarthana (2006:5), faktor - faktor yang perlu diperhatikan dalam meningkatkan tingkat hunian kamar antara lain adalah lokasi hotel, fasilitas hotel, pelayanan kamar, harga kamar dan promosi.

Berdasarkan uraian diatas, maka tujuan dari penelitian ini adalah untuk mengetahui faktor-faktor apa saja yang mempengaruhi tingkat hunian kamar hotel di kota Jember.

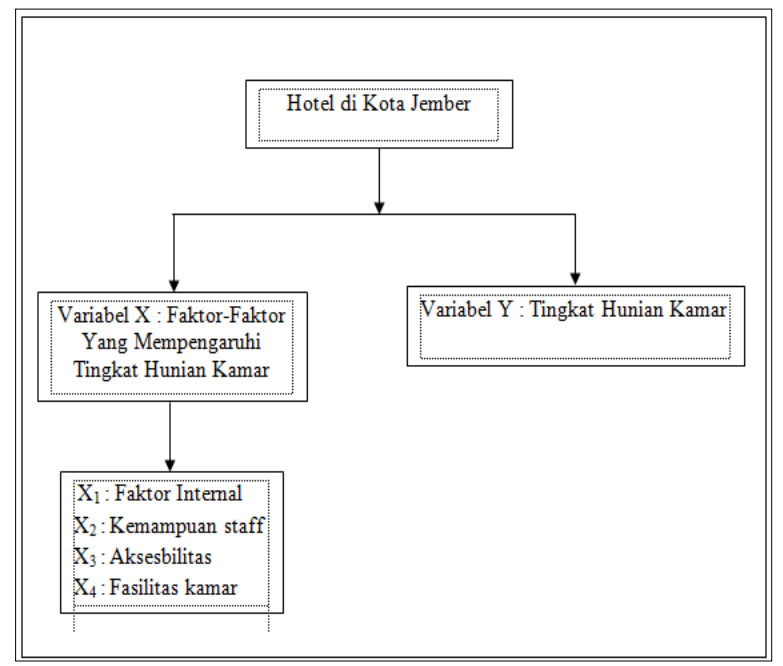

Gambar 1. Kerangka Pemikiran

\section{METODOLOGI}

Penelitian ini menggunakan analisis deskriptif adalah statistik yang digunakan untuk menganalisa data dengan cara 
Sadar Wisata: Jurnal Pariwisata

(p-ISSN 1858-0112, e-ISSN 15537-37677)

mendeskripsikan atau menggambarkan data yang telah terkumpul sebagaimana adanya tanpa bermaksud membuat kesimpulan yang berlaku untuk umum atau generalisasi (Sugiyono, 2004:169).

Sumber data yang digunakan adalah :

1. Data primer adalah data yang langsung diperoleh di objek penelitian baik dari hasil observasi langsung maupun dari responden, seperti keadaan atau kondisi hotel di kota Jember. Jumlah sampelnya 75 responden karyawan hotel, dan 150 responden pengunjung hotel

2. Data Sekunder adalah data yang diperoleh dari pihak-pihak tertentu berupa pencatatan-pencatatan formal dan bukan merupakan sumber pertama misalnya data diperoleh dari institusi terkait seperti PHRI cabang Jember, Kantor Pariwisata Jember dan sebagainya yang disesuaikan dengan kebutuhan penelitian. Data ini bersifat melengkapi data primer sekaligus sebagai data komparasi untuk menjawab permasalahan penelitian, yaitu mengetahui faktor - faktor yang mempengaruhi tingkat hunian kamar. Jumlah sampelnya 110 responden masyarakat, dan 150 responden wisatawan.

Proses analisis penelitian ini dimulai dengan menyusun semua data-data yang diperoleh dari berbagai sumber, baik dari hasil kuesioner, wawancara langsung, pengamatan di lapangan. Melakukan Analisis deskriptif berdasarkan hasil kuantitatif dengan data-data yang ada diproses melalui pengelompokkan data.

\section{RESULT AND DISCUSSION}

Berdasarkan hasil wawancara dengan beberapa pihak diantara Dinas Pariwisata Kota Jember dan Perhimpunan Hotel dan Restoran Indonesia Kota Jember diperoleh gambaran mengenai potensi
Volume 3 No. 1 Juni Tahun 2020

http://jurnal.unmuhjember.ac.id/index.php/wisata

pertumbuhan hotel yang signifikan di Kota Jember dan disertai dengan tingkat hunian kamar bagus.

Klasifikasi hotel di Jember yang beragam, mulai hotel kecil sampai besar dan hotel melati sampai bintang secara bersama berkompetisi untuk mendapatkan tamu sebagai upaya meningkatkan tingkat hunian kamarnya masing - masing. Maka perlu di ketahui faktor apa sajakah yang mempengaruhinya.

\section{Uji Validitas}

Validitas mempunyai arti sejauh mana ketepatan dan kecermatan suatu alat ukur (dalam hal ini kuesioner) melakukan fungsi ukurnya. Pengujian validitas dalam penelitian ini dilakukan dengan korelasi Pearson Validity dengan teknik product moment. Hasil uji validitas dapat dilihat pada tabel berikut :

Tabel. 1 Rekapitulasi Hasil Uji Validitas

\begin{tabular}{|c|c|c|c|c|}
\hline Variabel & Indikator & r hitung & Sig. & Keterangan \\
\hline \multirow{4}{*}{ Faktor Intemal } & $\mathrm{X}_{1.1}$ & 0,718 & 0,000 & Valid \\
\hline & $\mathrm{X}_{1.2}$ & 0,802 & 0,000 & Valid \\
\hline & $\mathrm{X}_{1.3}$ & 0,661 & 0,000 & Valid \\
\hline & $\mathrm{X}_{1.4}$ & 0,376 & 0,000 & Valid \\
\hline \multirow{3}{*}{$\begin{array}{l}\text { Kemampuan } \\
\text { Staff }\end{array}$} & $\mathrm{X}_{2.1}$ & 0,697 & 0,000 & Valid \\
\hline & $\mathrm{X}_{2.2}$ & 0,759 & 0,000 & Valid \\
\hline & $\mathrm{X}_{2.3}$ & 0,756 & 0,000 & Valid \\
\hline \multirow{2}{*}{ Aksesbilitas } & $\mathrm{X}_{3.1}$ & 0,720 & 0,000 & Valid \\
\hline & $\mathrm{X}_{3.1}$ & 0,779 & 0,000 & Valid \\
\hline \multirow{4}{*}{ Fasilitas Kamar } & $\mathrm{X}_{4.1}$ & 0,552 & 0,000 & Valid \\
\hline & $\mathrm{X}_{4.2}$ & 0,686 & 0,000 & Valid \\
\hline & $\mathrm{X}_{4.3}$ & 0,606 & 0,000 & Valid \\
\hline & $\mathrm{X}_{4.4}$ & 0,656 & 0,000 & Valid \\
\hline \multirow{3}{*}{$\begin{array}{l}\text { Tingkat Hunian } \\
\text { Kamar }\end{array}$} & $\mathrm{Y}_{1}$ & 0,724 & 0,000 & Valid \\
\hline & $\mathrm{Y}_{2}$ & 0,838 & 0,000 & Valid \\
\hline & $\mathrm{Y}_{3}$ & 0,791 & 0,000 & Valid \\
\hline
\end{tabular}

Berdasarkan Tabel. 1 dapat diketahui bahwa masing-masing indikator yang digunakan baik dalam variabel independen (Faktor Internal, Kemampuan Staff, Aksesbilitas, dan Fasilitas Kamar) maupun variabel dependen (Tingkat Hunian Kamar) mempunyai nilai signifikansi yang lebih kecil dari 0,05 . Hal ini berarti indikator- 
Sadar Wisata: Jurnal Pariwisata

(p-ISSN 1858-0112, e-ISSN 15537-37677)

indikator yang digunakan dalam variabel penelitian ini layak atau valid digunakan sebagai pengumpul data.

\section{Uji Reliabilitas}

Pengujian ini dilakukan untuk menunjukkan sejauh mana suatu hasil pengukuran relatif konsisten. Suatu pertanyaan yang baik adalah pertanyaan yang jelas mudah dipahami dan memiliki interpretasi yang sama meskipun disampaikan kepada responden yang berbeda dan waktu yang berlainan. Hasil pengujian reliabilitas adalah sebagai berikut :

Tabel. 2 Hasil Uji Reliabilitas

\begin{tabular}{|l|c|c|}
\hline \multicolumn{1}{|c|}{ Variabel } & $\alpha$ & Keterangan \\
\hline Faktor Intemal & 0,611 & \\
Kemampuan Staff & 0,566 & \\
Aksesbilitas & 0,622 & Reliabel \\
Fasilitas Kamar & 0,647 & $\alpha>0,50$ \\
Tingkat Hunian Kamar & 0,689 & \\
\hline
\end{tabular}

Berdasarkan Tabel. 2 dapat disimpulkan bahwa semua variabel yang digunakan dalam penelitian ini adalah reliabel, karena memiliki nilai Cronbach Alpha $(\alpha)$ lebih besar dari 0,50. Sesuai yang disyaratkan oleh Ghozali (2000) bahwa suatu konstruk dikatakan reliabel jika nilai Cronbach Alpha lebih dari 0,50.

\section{Analisis Regresi Linier Berganda.}

Pengujian regresi linear berganda berguna untuk mengetahui tingkat pengaruh variabel independen (Faktor Internal, Kemampuan Staff, Aksesbilitas, dan Fasilitas Kamar) terhadap variabel dependen (Tingkat Hunian Kamar). Berdasarkan pengujian dengan bantuan program SPSS for Windows 17.0 diperoleh hasil yang dapat disajikan dalam tabel berikut:
Volume 3 No. 1 Juni Tahun 2020

http://jurnal.unmuhjember.ac.id/index.php/wisata

Tabel. 3 Hasil Perhitungan Regresi Linear Berganda

\begin{tabular}{|l|c|c|c|c|}
\hline \multicolumn{1}{|c|}{ Variabel } & Koef. Regresi & $\mathbf{t}_{\text {hitung }}$ & Sig. & Keterangan \\
\hline Konstanta & $-2,194$ & $-1,981$ & 0,049 & \\
\hline Faktor Intemal & 0,338 & 4,491 & 0,000 & Signifikan \\
\hline Kemampuan Staff & 0,258 & 3,191 & 0,002 & Signifikan \\
\hline Aksesbilitas & 0,424 & 3,663 & 0,000 & Signifikan \\
\hline Fasilitas Kamar & 0,227 & 3,002 & 0,003 & Signifikan \\
\hline
\end{tabular}

Berdasarkan hasil tersebut dapat diperoleh persamaan regresi linier berganda sebagai berikut:

$\mathrm{Y}=-2,194+0,338 \mathrm{X}_{1}+0,258 \mathrm{X}_{2}+0,424$ $\mathrm{X}_{3}+0,227 \mathrm{X}_{4}+\mathrm{e}$

Interpretasi atas hasil analisis tersebut dapat dinyatakan sebagai berikut:

1. Konstanta sebesar -2,194, menunjukkan besanya Tingkat Hunian Kamar pada saat variabel Faktor Internal, Kemampuan Staff, Aksesbilitas, dan Fasilitas Kamar sama dengan nol. Dalam hal ini Tingkat Hunian Kamar akan mengalami penurunan tanpa keempat variabel tersebut yang disebabkan oleh faktor lain.

2. $b_{1}=0,338$, artinya apabila variabel Kemampuan Staff, Aksesbilitas, dan Fasilitas Kamar sama dengan nol, maka peningkatan variabel Faktor Internal akan meningkatkan Tingkat Hunian Kamar.

3. $\mathrm{b}_{2}=0,258$, artinya apabila variabel Faktor Internal, Aksesbilitas, dan Fasilitas Kamar sama dengan nol, maka peningkatan variabel Kemampuan Staff akan meningkatkan Tingkat Hunian Kamar.

4. $\mathrm{b}_{3}=0,424$, artinya apabila variabel Faktor Internal, Kemampuan Staff, dan Fasilitas Kamar sama dengan nol, maka peningkatan variabel Aksesbilitas akan meningkatkan Tingkat Hunian Kamar. 
Sadar Wisata: Jurnal Pariwisata

(p-ISSN 1858-0112, e-ISSN 15537-37677)

5. $\mathrm{b}_{4}=0,227$, artinya apabila variabel Faktor Internal, Kemampuan Staff, dan Aksesbilitas sama dengan nol, maka peningkatan variabel Fasilitas Kamar akan meningkatkan Tingkat Hunian Kamar.

Pengujian Secara Bersama-sama (Uji F)

Pengujian ini bertujuan untuk mengetahui pengaruh variabel Faktor Internal, Kemampuan Staff, Aksesbilitas, dan Fasilitas Kamar terhadap Tingkat Hunian Kamar secara bersama-sama. Secara bersama-sama Faktor Internal, Kemampuan Staff, Aksesbilitas, dan Fasilitas Kamar akan terbukti berpengaruh secara signifikan terhadap Tingkat Hunian Kamar jika probabilitas signifikansi $<0,05$. Sebaliknya jika probabilitas signifikansi > 0,05 maka variabel Faktor Internal, Kemampuan Staff, Aksesbilitas, dan Fasilitas Kamar tidak berpengaruh secara signifikan terhadap Tingkat Hunian Kamar. Adapun hasil uji F dapat dilihat pada tabel berikut :

Tabel. 4 Hasil Perhitungan Uji

\begin{tabular}{|c|c|c|c|c|c|}
\hline Dependent Variable & Intependent Variable & R Square & $\mathrm{F}_{\text {binug }}$ & Sig. \\
\hline $\mathrm{Y}$ & $\mathrm{X}_{1} \mathrm{X}_{2} \mathrm{X}_{3} \mathrm{X}_{4}$ & 0,524 & 39,854 & 0,000 \\
\hline
\end{tabular}

Berdasarkan Tabel. 4 dapat dilihat bahwa nilai probabilitas signifikansi uji $\mathrm{F}$ lebih kecil dari $0,05(0,000<0,05)$, maka Faktor Internal, Kemampuan Staff, Aksesbilitas, dan Fasilitas Kamar secara bersama-sama berpengaruh positif dan signifikan terhadap Tingkat Hunian Kamar pada tingkat signifikan 5\%. Sehingga, hipotesis yang menyatakan faktor internal, kemampuan staff, aksesbilitas, dan fasilitas kamar berpengaruh signifikan secara bersama-sama terhadap tingkat hunian kamar hotel di Jember.

Koefisien Determinasi Berganda $\left(\mathbf{R}^{\mathbf{2}}\right)$

Nilai koefisien determinasi berganda $\left(R^{2}\right)$ dimaksudkan untuk mengetahui besarnya
Volume 3 No. 1 Juni Tahun 2020

http://jurnal.unmuhjember.ac.id/index.php/wisata

sumbangan dari variabel bebas terhadap variabel terikat. Nilai koefisien determinasi terletak antara 0 dan 1. Apabila $\mathrm{R}$ square atau $\mathrm{R}^{2}=1$, maka garis regresi dari model tersebut memberikan sumbangan sebesar $100 \%$ terhadap perubahan variabel terikat. Apabila $\mathrm{R}^{2}=0$, maka model tersebut tidak bisa mempengaruhi atau tidak bisa memberikan sumbangan terhadap perubahan variabel terikat. Kecocokan model akan semakin lebih baik apabila mendekati satu.

Berdasarkan hasil analisis yang bisa dilihat pada Tabel. 4 diperoleh hasil koefisien determinasi berganda $\left(\mathrm{R}^{2}\right)$ sebesar 0,524 , hal ini berarti $52,4 \%$ perubahan tingkat hunian kamar dipengaruhi oleh variabel faktor internal, kemampuan staff, aksesbilitas, dan fasilitas kamar sedangkan sisanya sebesar $47,6 \%$ disebabkan oleh faktor lain yang tidak termasuk dalam persamaan regresi yang dibuat.

\section{Pengujian Secara Parsial (Uji t)}

Pengujian ini dimaksudkan untuk mengetahui pengaruh masing-masing variabel independen terhadap variabel dependen. Caranya adalah dengan membandingkan nilai statistik $t_{\text {hitung dengan }}$ nilai statistik $t_{\text {tabel }}$ dengan tingkat signifikan ( $\alpha$ ) yang digunakan yaitu 5\%. Masingmasing variabel bebas dikatakan mempunyai pengaruh yang signifikan (nyata) apabila apabila probabilitas $<5 \%(\alpha)$.

Hasil perhitungan uji t dengan menggunakan program SPSS for Windows dapat dilihat pada Tabel. 3 Berdasarkan tabel tersebut dapat diketahui besarnya pengaruh masingmasing variabel bebas terhadap variabel terikat sebagai berikut:

1. Pengaruh variabel Faktor Internal $\left(\mathrm{X}_{1}\right)$ terhadap Tingkat Hunian Kamar (Y)

Berdasarkan Tabel. 3 dapat diketahui bahwa thitung sebesar 4,491 dan signifikansi $<\alpha$ yaitu $0,000<0,05$. Karena tingkat probabilitasnya lebih kecil dari $5 \%$, maka $\mathrm{H}_{0}$ ditolak, berarti secara 
Sadar Wisata: Jurnal Pariwisata

(p-ISSN 1858-0112, e-ISSN 15537-37677)

parsial variabel faktor internal $\left(\mathrm{X}_{1}\right)$ mempunyai pengaruh signifikan terhadap tingkat hunian kamar hotel di Jember (Y). Sehingga, hipotesis yang menyatakan faktor internal memiliki pengaruh signifikan terhadap tingkat hunian kamar hotel di Jember terbukti kebenarannya (Ha ${ }_{1}$ diterima.

2. Pengaruh variabel Kemampuan $\operatorname{Staff}\left(\mathrm{X}_{2}\right)$ terhadap Tingkat Hunian Kamar (Y).

Berdasarkan Tabel. 3 dapat diketahui bahwa thitung sebesar 3,191 dan signifikansi $<\alpha$ yaitu $0,002<0,05$. Karena tingkat probabilitasnya lebih kecil dari 5\%, maka $\mathrm{H}_{0}$ ditolak, berarti secara parsial variabel kemampuan staff $\left(\mathrm{X}_{2}\right)$ mempunyai pengaruh signifikan terhadap tingkat hunian kamar hotel di Jember (Y). Sehingga, hipotesis yang menyatakan kemampuan staff memiliki pengaruh signifikan terhadap tingkat hunian kamar hotel di Jember terbukti kebenarannya ( $\mathrm{Ha}_{2}$ diterima).

3. Pengaruh variabel Aksesbilitas $\left(\mathrm{X}_{3}\right)$ terhadap Tingkat Hunian Kamar (Y).

Berdasarkan Tabel. 3 dapat diketahui bahwa $t_{\text {hitung }}$ sebesar 3,663 dan signifikansi $<\alpha$ yaitu $0,000<0,05$. Karena tingkat probabilitasnya lebih kecil dari $5 \%$, maka $\mathrm{H}_{0}$ ditolak, berarti secara parsial variabel aksesbilitas $\left(\mathrm{X}_{3}\right)$ mempunyai pengaruh signifikan terhadap tingkat hunian kamar hotel di Jember (Y). Sehingga, hipotesis yang menyatakan aksesbilitas memiliki pengaruh signifikan terhadap tingkat hunian kamar hotel di Jember terbukti kebenarannya ( $\mathrm{Ha}_{3}$ diterima).

4. Pengaruh variabel Fasilitas $\operatorname{Kamar}\left(\mathrm{X}_{4}\right)$ terhadap Tingkat Hunian Kamar (Y).

Berdasarkan Tabel 4.9 dapat diketahui bahwa thitung sebesar 3,002 dan signifikansi $<\alpha$ yaitu $0,003<0,05$. Karena tingkat probabilitasnya lebih kecil dari $5 \%$, maka $\mathrm{H}_{0}$ ditolak, berarti secara
Volume 3 No. 1 Juni Tahun 2020

http://jurnal.unmuhjember.ac.id/index.php/wisata

parsial variabel fasilitas kamar $\left(\mathrm{X}_{4}\right)$ mempunyai pengaruh signifikan terhadap tingkat hunian kamar hotel di Jember (Y). Sehingga, hipotesis yang menyatakan fasilitas kamar memiliki pengaruh signifikan terhadap tingkat hunian kamar hotel di Jember terbukti kebenarannya (Ha4 diterima).

Analisis Koefisien Korelasi Parsial (r).

Koefisien korelasi parsial merupakan koefisien untuk mengukur keeratan hubungan dari dua variabel, sedangkan variabel lainnya dianggap konstan (tidak memberikan pengaruh) pada hubungan yang melibatkan lebih dari dua variabel (Hasan, 2004: 69). Berdasarkan hasil analisis regresi dapat diketahui bahwa besarnya koefisien korelasi parsial masing-masing variabel adalah sebagai berikut :

Tabel. 5 Koefisien Korelasi Parsial.

\begin{tabular}{|l|c|}
\hline \multicolumn{1}{|c|}{ Variabel } & $\mathrm{r}_{\text {partial }}$ \\
\hline Faktor Intemal & 0,349 \\
\hline Kemampuan Staff & 0,256 \\
\hline Aksesbilitas & 0,291 \\
\hline Fasilitas Kamar & 0,242 \\
\hline
\end{tabular}

Berdasarkan koefisien korelasi parsial seperti yang terlihat pada tabel tersebut, maka dapat diketahui bahwa besarnya koefisien korelasi parsial untuk variabel faktor internal $\left(\mathrm{X}_{1}\right)$ adalah 0,349, kemampuan staff $\left(\mathrm{X}_{2}\right)$ adalah 0,256, aksesbilitas $\left(\mathrm{X}_{3}\right)$ adalah 0,291, dan fasilitas kamar $\left(\mathrm{X}_{4}\right)$ adalah 0,242. Berdasarkan hasil tersebut, dapat disimpulkan bahwa dari keempat variabel (faktor internal, kemampuan staff, aksesbilitas, dan fasilitas kamar) yang memiliki pengaruh dominan terhadap tingkat hunian kamar adalah variabel faktor internal. Sehingga hipotesis yang menyatakan diduga variabel faktor internal memiliki pengaruh dominan 
terhadap tingkat hunian kamar hotel di Jember kebenarannya $\left(\mathrm{H}_{\mathrm{a} 2}\right.$ diterima).

Setelah dilakukan pengujian statistik baik secara parsial (individu) dengan menggunakan uji t maupun secara simultan (bersama-sama) dengan menggunakan uji $\mathrm{F}$, maka analisis lebih lanjut dari hasil analisis regresi adalah :

1. Pengaruh Faktor Internal terhadap Tingkat Hunian Kamar.

Hasil uji regresi menunjukkan variabel Faktor Internal berpengaruh positif dan signifikan terhadap Tingkat Hunian Kamar dengan koefisien 0,338. Hal ini berarti faktor Faktor Internal yang diukur melalui hotel menawarkan harga yang sesuai dengan fasilitas yang ditawarkan, kualitas kamar yang ditawarkan hotel seseuai dengan harapan konsumen, lokasi hotel strategis dan mudah dijangkau dengan transportasi, dan kegiatan promosi yang dilakukan hotel baik intensitas maupun kualitasnya memadai merupakan suatu faktor yang menentukan Tingkat Hunian Kamar hotel di Jember.

2. Pengaruh Kemampuan Staff terhadap Tingkat Hunian Kamar.

Hasil uji regresi menunjukkan variabel Kemampuan Staff berpengaruh positif dan signifikan terhadap Tingkat Hunian Kamar dengan koefisien 0,258. Hal ini berarti faktor Kemampuan Staff yang diukur melalui karyawan tanggap dalam melayani konsumen, karyawan bersikap ramah dan sopan kepada konsumen, dan karyawan memiliki pengetahuan yang baik menganai fasilitas dan pelayanan hotel merupakan suatu faktor yang menentukan Tingkat Hunian Kamar hotel di Jember.

3. Pengaruh Aksesbilitas terhadap Tingkat Hunian Kamar

Hasil uji regresi menunjukkan variabel Aksesbilitas berpengaruh positif dan signifikan terhadap Tingkat Hunian Kamar dengan koefisien 0,424. Hal ini berarti faktor Aksesbilitas yang diukur melalui hotel menawarkan kecepatan layanan dan hotel menawarkan ketepatan layanan merupakan suatu faktor yang menentukan Tingkat Hunian Kamar hotel di Jember.

4. Pengaruh Fasilitas Kamar terhadap Tingkat Hunian Kamar.

Hasil uji regresi menunjukkan variabel Fasilitas Kamar berpengaruh positif dan signifikan terhadap Tingkat Hunian Kamar dengan koefisien 0,227. Hal ini berarti faktor Fasilitas Kamar yang diukur melalui hotel menawarkan kamar dengan desain interior yang menarik, hotel memiliki tata ruang yang baik, hotel menawarkan akses internet yang memadai, dan hotel menawarkan fasilitas pendukung seperti laundry, pemanas air, layanan kamar, dan lainnya yang memadaimerupakan suatu faktor yang menentukan Tingkat Hunian Kamar hotel di Jember.

\section{KESIMPULAN}

Berdasarkan hasil analisis, maka dapat diambil beberapa kesimpulan sebagai berikut:

1. Berdasarkan hasil uji $\mathrm{F}$, diperoleh hasil yang menyatakan bahwa faktor internal, kemampuan staff, aksesbilitas, dan fasilitas kamar berpengaruh signifikan secara bersama-sama terhadap tingkat hunian kamar hotel di Jember.

Berdasarkan hasil uji t, diperoleh hasil yang dapat dinyatakan bahwa faktor internal, kemampuan staff, aksesbilitas, dan fasilitas kamar berpengaruh signifikan secara parsial terhadap tingkat hunian kamar hotel di Jember. Adapun besarnya pengaruh dari masing-masing variabel independen dapat dilihat dari besarnya koefisien regresi yaitu untuk 
faktor internal $\left(\mathrm{X}_{1}\right)$ adalah 0,338, kemampuan staff $\left(\mathrm{X}_{2}\right)$ adalah 0,258 , aksesbilitas $\left(\mathrm{X}_{3}\right)$ adalah 0,424 , dan fasilitas kamar $\left(\mathrm{X}_{4}\right)$ adalah 0,227.

2. Berdasarkan koefisien korelasi parsial diketahui bahwa variabel faktor internal memiliki pengaruh dominan terhadap tingkat hunian kamar hotel di Jember dengan koefisien korelasi parsial sebesar 0,349

\section{SARAN}

Dari hasil penelitian ini kiranya peneliti dapat memberikan saran, diantaranya:

1. Hasil penelitian membuktikan bahwa faktor internal, kemampuan staff, aksesbilitas, dan fasilitas kamar berpengaruh signifikan terhadap tingkat hunian kamar hotel di Jember, oleh karena itu hendaknya perusahaan perhotelan di Jember selalu memperhatikan hal-hal khususnya yang berkaitan dengan kualitas layanan jasanya, seperti kesesuaian pelayanan dengan yang dijanjikan, perhatian penanganan keluhan Pengunjung hotel, pemahaman keinginan Pengunjung hotel, jaminan keamanan, kenyamanan, dan lain-lain.

2. Hasil penelitian ini hanya mampu menjelaskan tingkat hunian kamar sebesar 52,4\%, sehingga masih ada faktor lain di luar model yang diteliti yang mampu menjelaskan tingkat hunian kamar. Oleh karena itu disarankan bagi penelitian lanjutan untuk menambahkan variabel lain seperti citra atau image perusahaan, kepuasan konsumen, dan lain-lain. Sehingga dapat memperoleh hasil temuan yang lebih baik dan berguna bagi pengembangan ilmu pengetahuan.

\section{DAFTAR PUSTAKA}

Agusnawar, A.Md.Par. 2002. Pengantar Operasional Kantor Depan Hotel. Jakarta : PT. Perca

Darsono Agustinus. 2001. Kantor Depan Hotel. Jakarta : PT.Gramedia Widiasarana Indonesia.

Handoko T. Hadi. 2000. Manajemen Personalia Dan Sumberdaya Manusia. Yogyakarta : BPFE

Rangkuti, Freddy. 2001. Analisis SWOT Teknik Membedah Kasus Bisnis. Jakarta : Gramedia Pustaka Utama.

Suarthana. 2006. Manajemen Perhotelan Edisi Kantor Depan, Kuta Utara : Mapindo

Soekadijo. R. G. 2000. Anatomi Pariwisata. Jakarta : PT Gramedia Pustaka Umum.

Sugiarto Endar. 1996. Pengantar Akomodasi Dan Restoran. Jakarta : PT. Gramedia Pustaka Utama

Sugiarto, Endar. 2002. Hotel Front Office Administration ( Administrasi Kantor Depan Hotel ). Jakarta : PT. Gramedia Pustaka Utama.

Sugiyono. 2004. Metode Penelitian. Bandung: Alfabeta

Sulastyono, Agus. 2001. Manajemen Penyelenggaraan Hotel. Bandung : CV. Alfabeta

Sulastyono, Agus. 2008. Seri Manajemen Usaha jasa Sarana Pariwisata dan Akomodasi ; Teknik dan Prosedur Devisi Kamar. Bandung : CV. Alfabeta

Swastha, Basu dan Irawan. 1997. Manajemen Pemasaran Modern. Edisi kelima, Yogyakarta : Liberty.

Tjiptono, Fandi. 2001. "Strategi Pemasaran". Edisi kedua, Yogyakarta : Andi

Wahab, Salah. 1997. Pemasaran Pariwisata. Jakarta : PT. Pradya Paramitha. 
Sadar Wisata: Jurnal Pariwisata

(p-ISSN 1858-0112, e-ISSN 15537-37677)
Volume 3 No. 1 Juni Tahun 2020

http://jurnal.unmuhjember.ac.id/index.php/wisata

Yoeti, Oka. 1996. Pemasaran Pariwisata, Bandung : Angkasa Bandung.

Peraturan Daerah Nomor 9 Tahun 2011

Tentang Rencana Tata Ruang

Wilayah Kabupaten Bima 2011-2031

BPS Kabupaten Bima dalam angka (2018) 